\title{
Should I Stay or Should I Go Now? Partisanship, Approval, and the Duration of Major Power Democratic Military Interventions
}

\author{
Michael T. Koch Texas A\&M University \\ Patricia Sullivan University of Georgia
}

\begin{abstract}
How does the domestic political climate within democratic states affect the duration of their foreign military engagements? To answer this question we combine a rationalist model of war termination with a theory about how partisan politics affects the policy preferences of national leaders to predict the duration of democratic military interventions. Specifically, we examine how changes in a chief executive's public approval ratings interact with partisanship to affect decisions about the timing of conflict termination. We test our expectations on a set of 47 British, French, and American cases from a new dataset of military interventions by powerful states. Our results suggest that partisanship mediates the effect of public approval on the duration of military operations initiated by powerful democratic countries. As executive approval declines, governments on the right of the political spectrum are inclined to continue to fight, while left-leaning executives become more likely to bring the troops home.
\end{abstract}

By stepping up the American military presence in Iraq, President Bush is not only inviting an epic clash with the Democrats who run Capitol Hill. He is ignoring the results of the November elections...

—Sheryl Gay Stolberg, New York Times, January 11, 2007

In March of 2003, after the onset of the current U.S. military intervention in Iraq, President Bush's job approval ratings soared to over $70 \%$. After one year of fighting in Iraq, the president's approval ratings hovered around $50 \%$. By the third year of the war, the percentage of the public approving of the president's job performance had fallen into the 30s. President Bush's approval ratings never exceeded $41 \%$ and frequently dipped into the 20 s for the remainder of his term. As early as June of 2005, a bipartisan group of representatives introduced a joint resolution (HJ Res 55) requiring the President to implement a plan for the withdrawal of U.S. troops from Iraq. In a March 2006 ABC News/Washington Post survey, $57 \%$ of respondents thought the war in Iraq was not worth the cost and well over a majority believed the United States should begin to withdraw its troops. Even the troops deployed in Iraq expressed doubts about the mission. In a February 2006 poll conducted by Zogby international, only $23 \%$ of the soldiers polled agreed that U.S. troops should stay as long as necessary to achieve American objectives while $29 \%$ said they thought U.S. troops should withdraw "immediately."

Yet, the conflict in Iraq persisted. Rather than withdrawing U.S. military forces and ending the intervention, President Bush responded to declining public support with a public relations campaign designed to convince the public that the administration has a strategy for victory in Iraq. On January 10, 2007, President Bush defied the recommendations of a bipartisan Congressional panel's assessment of U.S. policy in Iraq and escalated the United States' commitment, announcing plans to send 21,500 more troops to Iraq.

In this study, we ask a straightforward question: how does the domestic political climate within democratic states affect the duration of their foreign military operations? In particular, we examine how changes in a chief executive's public approval ratings interact with partisanship to affect decisions about 
the timing of conflict termination. Our theoretical framework combines a rationalist approach to war termination decision making with a theory about how partisan politics and public opinion affect the policy preferences of national leaders. We test our expectations using event history analysis with the population of military interventions initiated by France, the United Kingdom, and the United States between 1960 and 2000 from a new dataset of major power military interventions.

Our study fills a gap in the literature on the nexus of domestic politics and international conflict. A significant body of literature explores the relationship between public approval and democratic leaders' decisions to use military force abroad. Numerous studies find that the use of force affects public support for national leaders. Other research shows that public opposition to or support for the use of military force abroad can influence whether a leader decides to use force in a particular situation. However, this literature focuses almost exclusively on the onset of militarized disputes or wars, and ignores how changes in public support for the chief executive affects conflict prosecution after the conflict has begun. The choice between war and peace is not a one-shot decision, but rather a continuous series of decisions with countless opportunities to escalate, sustain, deescalate, or terminate the fighting. If foreign policy success and failure affects the chief executive's public support-and public support is important to maintaining office-we should expect changes in leaders' job approval ratings to influence, not only decisions to use force, but also subsequent decisions about prosecuting and terminating military commitments.

Our study provides one of the first systematic, cross-national tests of how executive approval and partisan politics influence the duration and outcome of foreign military interventions. While studies of U.S. public opinion and foreign policy behavior dominate the empirical research, we look at the relationship between public support for the government in power and conflict trajectories in three major power democracies. We find evidence that changes in the level of public support for a chief executive affect the timing of conflict termination. However, consistent with our hypotheses, the political orientation of the government in power conditions the effect of shifts in executive approval. Governments of the left become more likely to withdraw their military forces as their job approval ratings decline while right party executives become less likely to terminate military interventions as their popularity declines.

\section{Public Opinion and the Use of Military Force}

One major theme of research concerned with the connection between public support for national leaders and foreign military involvement has been the "rally effect" presidents frequently enjoy when they use military force abroad. Although Lian and Oneal (1993) conclude that, on average, presidential approval does not change following foreign military operations, Brody (1991), Jordon and Page (1992), Mueller (1973), and Page and Brody (1972) all find that presidential approval often spikes when the president uses force abroad. More broadly, Ostrom and Simon (1985) show the U.S. public rewards the chief executive for tough military and foreign policy stances. And Oneal, Lian, and Joyner (1996) find that American presidents get a popularity boost from the public when they respond forcefully to aggression.

A related literature on diversionary war explores hypotheses about the effects of domestic political incentives to use military force abroad. However, empirical tests of the effect of U.S. presidential popularity on leaders' propensity to initiate the use of military force provide contradictory results. A significant amount of recent research concludes there is no direct relationship between low job approval ratings and foreign conflict involvement (DeRouen 2000; Fordham 2002b; Meernik and Waterman 1996; Mitchell and Moore 2002). But some studies have found evidence that declining approval rates among the public increase the probability of engagement in military action abroad (DeRouen 1995; Foster and Palmer 2006), while other scholars have found that the use of military force is more likely when public approval of the president is relatively high (James and Hristoulas 1994; James and Oneal 1991), or high but declining (Meernik 2000; Ostrom and Job 1986).

While there is mixed evidence about whether leaders deploy military troops to boost flagging approval ratings, only a handful of studies have explored the effects of the domestic political climate on conflict trajectories after the troops have been deployed. Sobel (2001), for example, finds that public opinion affects the timing and duration of U.S. military interventions. Meernik \& Brown (2007) find some evidence that, contrary to their expectations, higher levels of presidential approval decrease the duration of U.S. military engagements. While democratic publics may rally around the executive when deploying military troops, maintaining public support over the course of extended military engagements is difficult. Public 
approval of a war effort generally declines as the human and material costs of the war mount. As costs mount public discussion in the media and among elites becomes more critical (Baum 2000; Brody 1991; Gartner and Segura 1998; Larson 1996; Mueller 1973). The longer a conflict persists, the greater the human and material costs incurred by all parties and the larger its potential impact on leaders' political fortunes (Bennett and Stam 1996; Bueno de Mesquita, Koch and Siverson 2004; Bueno de Mesquita and Siverson 1995; Chiozza and Goemans 2004; Meernik and Brown 2007).

In the next section we discuss a simple model of war initiation and termination. We then develop a theory about how partisan accountability and changes in public approval influence leaders' recurring decisions about whether to sustain or terminate their foreign military commitments. We test the implications of this theory for the duration of foreign military operations using data on British, French, and American military interventions since 1960.

\section{Theory}

Like many other scholars, we view violent conflict as a bargaining process. Belligerents use force to change their opponent's beliefs about the probability and/or cost of victory in an attempt to coerce their opponent into settling on more favorable terms (Wagner 2000). All else equal, the probability that a state will make concessions to terminate a war increases when the leader's estimate of the cost of attaining the state's war aims increases, or the leader's estimate of the likelihood of victory decreases (Goemans 2000; Slantchev 2004).

War fighting is tremendously costly. Using military force results in the loss of economic resources, material, and human lives, and these costs can have political repercussions for national leaders. Public support for the chief executive is likely to suffer as casualties mount and the public begins to doubt the war effort is progressing toward victory (Feaver and Gelpi 2004; Gartner and Segura 1998; Mueller 1973). However, while most scholars focus their attention on the political costs of fighting, ${ }^{1}$ choosing to terminate a war can also be politically costly for leaders. To terminate a war, leaders must often make

${ }^{1}$ Filson and Werner (2007) is an important exception. The authors distinguish between sensitivity to the costs of fighting and sensitivity to making concessions. Their model suggests that the two sensitivities can have contradictory effects on the initiation, duration, and outcome of wars. some concessions to their adversary's demands or lower their own demands so that a negotiated settlement becomes possible. After sinking blood and treasure into a conflict, a leader who terminates a conflict without attaining the state's war aims may suffer a diminished international reputation for strength and resolve. At home, doubts about her competency can emerge, diminishing the leader's prospects for remaining in office (Bueno de Mesquita et al. 2003; Fearon 1994; Schultz 2001).

All else equal, the longer a leader can sustain the state's war efforts, the better the eventual settlement for that state. However, fighting longer also increases the human and material cost of war, which can erode the executive's domestic political support. After deploying the troops, leaders face a daily trade-off between the cost of continuing to fight and the cost of ending military operations on less favorable terms.

In the next section, we explain how the partisanship of the chief executive affects a leader's preferences in the face of this dilemma. We then generate testable hypotheses about the interactive effect of executive partisanship and executive approval on the likelihood that a leader terminates rather than sustains or escalates a conflict.

\section{Partisanship and Conflict Prosecution}

We present a theory of partisan accountability and foreign policy outcomes to explain why some leaders continue to fight while others terminate conflict under seemingly similar circumstances. We argue that executives primarily seek to satisfy the subset of the population whose support they must secure to remain in office-their "winning coalition"-rather than trying to satisfy all constituents. Because of the size of the winning coalition, democratic leaders must provide public goods to satisfy their winning coalition so that they, or their party, can retain office (Bueno de Mesquita et al. 2003). While democratic leaders must satisfy a broader constituency than nondemocratic leaders, they focus their efforts on their party and its partisans because this segment of the electorate makes up the largest proportion of their winning coalition. As Morgan and Bickers (1992) argue, erosion of support within their coalition concerns executives more than erosion of support among those who are not part of their domestic support base. Because elected leaders enact policies to satisfy the coalitions that keep them in office, 
examining the partisan base of support of presidents and prime ministers can help us predict what types of policies executives will prefer.

We draw on recent research providing evidence that, even when a broad national consensus exists on the primary foreign threat or issue, partisan differences exist over foreign policy preferences (Fordham 2002a). ${ }^{2}$ Holsti (2004), for example, finds that while there was broad public support for the first Persian Gulf War after the U.S. invasion of Iraq in 1991, rather substantial partisan differences still existed. And while there is wide variability in policy preferences within parties, in general, contemporary rightparty constituents tend to be more focused on preserving access to foreign markets and resources and increasing national security (Boix 1998), while left party identifiers primarily prioritize domestic issues such as welfare, redistribution of resources, employment, and health care (van der Brug 2001). Because wars divert resources away from the domestic policy priorities of left party constituents, governments of the left may be more sensitive to the domestic political costs of using force abroad (Koch 2009; Palmer, London, and Regan 2004).

Our own plausibility probes with public opinion data from the United Kingdom, France, and the United States reveal several trends. In a sample of 38 surveys conducted during U.S. military interventions between 1973 and 1999, Republicans were significantly more likely to support sustaining ongoing military operations than Democrats. In $\mathrm{Na}-$ tional Election Surveys (NES) conducted between 1980 and 2004, fewer than 9\% of Republicans, but more than $24 \%$ of Democrats expressed a preference for lower defense spending. British Election Surveys (BES) conducted in the United Kingdom between 1983 and 1992 reveal comparable trends; almost 30\% of Labour party supporters thought the government should spend less on the military, while only $11 \%$ of Conservatives wanted lower defense spending. Finally, according to a series of IFOP polls in France, clear partisan differences emerged over Algerian independence, the use of force over the Suez Canal, and the development of independent strategic nuclear capabilities. In each case, parties on the right took a more hawkish stance.

\footnotetext{
${ }^{2}$ The foreign policy preferences of political parties of the right and the left have changed over time. Numerous scholars argue that there was a significant partisan realignment during the Vietnam War in the United States (see, for example, Holsti 2004; McCormick \& Wittkopf 1990; and Sigelman 1979). Our argument and findings should be considered historically contingent.
}

Evidence also exists that left and right governments adopt different military and foreign policies. At least since the Vietnam War, parties with conservative political ideologies have tended to emphasize a strong or expanded military presence at home while liberal parties have leaned toward a diminished military presence (Eichenberg 1989; Schultz 2001). In Western European democracies, "conservative" parties are more likely than "liberal" parties to support increasing military spending and expanding the country's military presence abroad (Klingemann, Hofbert, and Budge 1994). And several studies conclude that conservative governments are more likely to use force in the international arena than are more liberal governments (Foster and Palmer 2006; Koch 2009; Palmer, London, and Regan 2004).

Because of the preferences and priorities of their core constituents, we expect the domestic political cost of expending blood and treasure in a foreign military contest to be lower for right party leaders than for left party leaders. At the same time, right party constituents are more likely to punish leaders for making concessions to end a war. As a result, when facing a trade-off between a shorter war with a less favorable settlement and a longer war with greater gains, right party leaders may be safer choosing the latter. Left-leaning governments, on the other hand, are more at risk of alienating their base of support by sustaining the use of military force abroad. All else equal, the constituency of left-leaning executives is likely to prefer a less favorable war outcome to a protracted military engagement.

\section{Partisanship, Executive Approval, and Conflict Termination}

While not every executive decision is made with an eye on the polls, executive approval is important to national leaders. High approval ratings facilitate executives advancing their policy agendas (Bond and Fleisher 1990; Rivers and Rose 1985; Rohde and Simon 1985). An executive's popularity has a strong bearing on the likelihood of reelection (Brody and Seligman 1983; Erickson 1989). And, in parliamentary systems, executive approval correlates directly with expected gains and losses in party seat share in the next legislative election (Jacobson 1992; Kernell 1977; Tufte 1975). Mueller (1973) suggests that approval reflects a process whereby the president's winning coalition "sheds" various minority coalitions over time during a war. As an executive's base of support erodes, 
she and her party face less favorable election odds and it becomes more difficult to accomplish other political goals.

Because of this threat of defection, governments should be cautious about adopting or maintaining policies that are inconsistent with the preferences of their partisan constituents when overall public approval is low. Leaders with high levels of public support can afford to initiate and sustain policies that may not be as popular with their core constituents (Meernik and Brown 2007). Because low approval ratings constrain governments, they may hope to rally supporters by changing policies that are unpopular with their base.

Decision makers do not have complete information about the military capabilities or resolve of their adversaries when deciding whether to initiate a military intervention. As a result, they may use military force and then find attaining their original objectives is more costly than originally expected. Leaders then face a trade-off between the costs of continuing to fight and the domestic political costs of "quitting" short of victory. We argue that whether terminating or sustaining a foreign military operation is a safer response to low levels of public approval depends on the partisan ideology of a leader's core constituency. As their public approval ratings decline, executives from right-oriented political parties should become less likely to terminate a foreign military intervention, while left-leaning executives should become more likely to bring the troops home.

We expect that right party executives can sustain the support of their core constituency over a longer duration, even if the prospects for victory decline. At the same time, right-party constituents are more likely to punish leaders for failing to achieve victory. Therefore right-party leaders are less likely to withdraw their country's military troops from combat short of victory (i.e., "quit') when faced with low domestic approval rates.

H1: Chief executives from parties on the political right become less likely to terminate a military mission short of victory as public approval declines.

Left-leaning governments, on the other hand, risk alienating their base of support by continuing military interventions with poor prospects for success. When overall public approval levels are low, left party leaders are more likely to cut their losses and withdraw.

H2: Chief executives from parties on the political left become more likely to terminate a military mission short of victory as public approval declines.

\section{Research Design}

We estimate Cox competing risks proportional hazards models with time-varying covariates to examine how approval and partisanship affect the duration of foreign military interventions conducted by democratic states. By using the Cox model we avoid any parametric assumptions about the shape of the baseline hazard, although the model does impose a proportional hazard assumption. The trade-off is between efficiency and ease of interpretation (the parametric model) and avoiding misspecification (the Cox model) (Box-Steffensmeier and Jones 2004). Our cases consist of all military interventions initiated by France, the United Kingdom, and the United States between 1960 and 2000 and are from the Military Intervention by Powerful States (MIPS) dataset (Sullivan and Koch 2009). The MIPS data defines a military intervention as a use of armed force that involves the official deployment of at least 500 regular military personnel (ground, air, or naval) to attain immediate-term political objectives through action against a foreign adversary. There are 47 interventions against both state and nonstate adversaries during the time period under investigation. ${ }^{3}$ The unit of analysis is the military interventionmonth.

Major power military interventions are "wars of choice" in the sense that the major powers face no immediate threat to their homeland or political survival and can choose whether to initiate, and when to terminate, from these foreign engagements. As a result, we can meaningfully discuss the duration of these interventions in terms of the intervening state's decision to persist or withdraw. In a broader population of cases we would need to consider the possibility that the conflict initiator could be rendered incapable of continuing to fight-or that the initiator might want to negotiate an end to the conflict but not able to because the other actor would not agree to stop fighting (Goemans 2000). In the cases we examine, the major powers were never militarily defeated or fighting to defend their homelands, so it is appropriate to view the timing of intervention termination as largely determined by the intervening state. The duration of the interventions

\footnotetext{
${ }^{3}$ There are 21 U.S., 13 British, and 13 French interventions. The models in this paper are estimated on 46 cases because we drop one intervention (an operation by French paratroopers to take out the Bokassa regime in the Central African Republic) that lasts less than two days. The effects of our key independent variables are robust to the inclusion of this case.
} 
ranges from one month to 128 months. The mean duration is almost 16 months (15.8), while the median duration is six months.

We employ a competing risks modeling strategy because military interventions can end in more than one way. While we are only interested in the effects of partisanship and approval on the propensity of governments to withdraw from foreign engagements short of victory (i.e., "quit"), about $63 \%$ of the military interventions in our dataset are terminated after the intervening state attains its primary political objective (the definition of "winning" employed in the MIPS dataset). We observe only one type of termination for each military intervention, but we assume that every military intervention has the potential to end in either intervening state victory or withdrawal and that, conditional on the independent variables, the hazards are independent. We estimate separate models for the hazard of quitting and prevailing, treating failures due to the alternative termination type as right-censored in each model. However, because we do not have any theoretical expectations about the effects of partisanship and approval on the probability of victory in war, we focus on substantive interpretation of only the withdrawal equation. The intervening state quits in fifteen and prevails in 29 of the 46 intervention cases in our dataset. We observe a total of 793 interventionmonths.

Our two primary independent variables are the partisan orientation of the executive and public approval of the executive. We create a dichotomous variable labeled Right Executive. For the United States, right executive is coded as 1 when the president is Republican. For the United Kingdom, right executive is coded as 1 when the Prime Minister is from the Conservative party. For France right executive is coded as one when the President is a member of the Gaullist party or one of its successor parties. To code Executive Approval we use monthly Gallup data on presidential approval for the United States. French approval data, which are similar to U.S. presidential approval data, are from TNS Sofres. For the United Kingdom, we use monthly prime minister satisfaction data drawn from British Political Facts (Butler and Butler 2000) and Gallup. We lag the executive approval variable by one month so we capture the effects of changes in approval on decisions to sustain or terminate an intervention in the following month. Because we are interested in how the political orientation of the chief executive conditions the effect of approval, we interact right executive with executive approval.

\section{Control Variables}

To control for possible selection effects that link initial conditions to subsequent outcomes we create a variable (Start Approval) that indicates the level of executive approval in the month before the state initiates the use of force. We also create a trichotomous measure of initial public support for the military intervention (Initial Support). Using public opinion surveys, as well as news accounts and secondary sources, we code each intervention as having active support, no dissent, or active dissent. ${ }^{4}$

Regardless of their own political orientation, leaders may find it easier to terminate military engagements, especially failing foreign interventions, if they are of a different party than the government that started the intervention. A dichotomous variable labeled Party Change indicates the partisanship of the government in a particular intervention-month is different from the partisanship of the government that made the initial decision to deploy troops. The partisanship of a country's chief executive changes during seven of the interventions.

Election cycles may also affect public approval, the strength of an executive's desire to manipulate approval, and policy choices. To control for the effect of elections on the duration of military interventions we create a variable labeled Election Timing that is equal to the number of months remaining until the next mandated election. We use data from Woldendorp, Keman, and Budge (2001) to determine when the next mandated election will occur.

We include monthly measures of economic performance because executive approval is often a function of how satisfied the electorate is with economic conditions (Brace and Hinkley 1991) and because a number of studies suggest that economic conditions have a direct impact on decisions to use force (e.g., DeRouen 2000; Ostrom and Job 1986; Oneal and Tir 2006; Russett 1990). French economic data are from the Institut National de la Statistique e des Etudes Economiques. British economic data are from the United Kingdom's Office of National Statistics. Economic data for the United States are from the Federal Register of the United States. We employ lagged, monthly measures of the unemployment rate and inflation.

To account for attributes of the military interventions that might be correlated with intervention

\footnotetext{
${ }^{4}$ We employed survey results where possible. However there are very few surveys about support for most of the interventions in the 1960s. To discern whether there was support or dissent, we examined whether there was editorial debate in the major newspapers over the intervention in its initial stages.
} 
duration and government partisanship or approval rates, we include several control variables. The manner and intensity of force employed is likely to affect the duration and outcome of military interventions, as well as the chief executive's job approval ratings (Goemans 2000; Gartner \& Segura 1998). While tracking changes in casualty rates and troop numbers would be ideal, reliable data are not available at a monthly level of analysis for most of the interventions. Instead, we create several different variables to capture these attributes. First, we create a measure of the initial number of troops deployed (Initial Troops). We also include a measure of additional troops deployed. The variable Force Change is the difference between the largest troop commitment of the intervention and the initial force deployed. We $\log$ these measures given expectations of declining marginal effects for each additional soldier. To control for how costly a particular foreign engagement is, we create a variable that measures the average number of battle deaths the intervening state suffers per month over the course of the intervention (Casualties). We also code whether the major power received assistance from another major power and whether the target was nonstate actor. We call these measures Coalition and Non-State Target respectively. We supplement the MIPS data with events data from three sources to create two measures that vary over the course of the interventions. The variables $M P$ Hostility and Target Hostility measure the average level of hostile activity one actor directs toward the other in a given month using events data from the KEDS (Gerner et al. 1994), WEIS (Goldstein 1992), and COPDAB (Azar 1993) datasets. ${ }^{5}$ We lag both MP Hostility and Target Hostility by one month.

Military intervention duration may also vary with the nature of the major power's war aims (Stam 1996; Sullivan 2007). At the same time, partisanship may affect the type of objectives a government chooses to pursue by using force and the issues at stake in the intervention should affect public approval (Jentleson 1992). We create a measure of the issue at stake using Jentleson and Britton's (1998) Principle Policy Objective (PPO) types and the MIPS dataset's objective variables. According to Jentleson and Britton, Foreign Policy Restraint (FPR) is defined as "the use of force to coerce an adversary engaged in aggressive actions

\footnotetext{
${ }^{5}$ The KEDS data and WEIS data use the same scale, with events given a score ranging from 11 to 223 (higher numbers mean more conflictual behavior). However, the COPDAB data ranges from 1 to 14 . Therefore, we recalibrated each so that the range is between -50 to 50 with higher number representing more conflictual and less cooperative behaviors (see appendix).
}

against the United States" (1992, 397). Internal Political Change (IPC) is defined as the use of force to try to "engineer internal political change in a government whether as support for the existing government or overthrowing a government considered an adversary" (397). The third category, $\mathrm{Hu}$ manitarian Intervention (HI) is defined as "The provision of emergency relief through military and other means to people suffering from famine or other gross and widespread humanitarian disasters" (399).

Finally, we create two dummy variables indicating when either France or Britain is the intervening state. These variables help to control for the possibility that the three democracies have different baseline hazards of withdrawal from foreign military engagements. Including these variables allows us to capture the effects of factors that may be unique to each country without specifying a laundry list of attributes. In addition to including the intervening state dummies as covariates, we estimate each of the models clustering on intervening state to account for non-independence among interventions conducted by a single major power.

\section{Results}

Table 1 presents results from estimation of Cox competing risks proportional hazards duration models. In Models 1 and 1a, the dependent variable is the duration of an intervention until the intervening state "quits" (withdraws without attaining the state's primary political objective). In this model, interventions that ended because the major power attained its primary political objective (prevailed) are treated as right-censored. The Cox proportional hazards model parameterizes the hazard rate $\mathrm{h}(\mathrm{t})$ in this manner, $h(t \mid X i)=h_{0}(t) e^{X i \beta}$ where $\mathrm{h}_{0}(\mathrm{t})$ is an unspecified nonnegative function of time. This is the baseline hazard. $X_{i}$ then is a covariate matrix for subject $\mathrm{j}$ where one or more of the covariates can vary across time.

A positive coefficient indicates an increase in the risk of intervention termination (decreasing intervention duration) and a negative coefficient indicates that an increase in that variable reduces the termination hazard. We test the proportional-hazards assumption for each model with estimated Schoenfeld residuals and find that none of the variables in either model violates the assumption. ${ }^{6}$

Model 1 contains only our key explanatory variables: the chief executive's public approval rate

\footnotetext{
${ }^{6}$ All results not displayed in the paper are available in the web appendix.
} 
Table 1 Cox Competing Risks Proportional Hazard Models: Duration until Major Power withdraws from intervention

\begin{tabular}{|c|c|c|c|c|c|}
\hline & Coefficient & $\begin{array}{c}\mathrm{Z} \\
\text { Score }\end{array}$ & Coefficient & $\begin{array}{c}\mathrm{Z} \\
\text { Score }\end{array}$ & $\begin{array}{c}\text { Hazard } \\
\text { Ratios } \\
\end{array}$ \\
\hline Right Party Executive & $-5.16^{\star * *}$ & $(4.84)$ & $-17.083^{\star * \star}$ & $(7.71)$ & $3.8 \mathrm{e}-08$ \\
\hline Executive Approval & $-0.060^{* * *}$ & (5.09) & $-.268^{\star \star \star}$ & $(10.74)$ & .764 \\
\hline Right x Approval & $0.104^{* * *}$ & $(6.85)$ & $0.342^{\star * *}$ & $(9.19)$ & 1.41 \\
\hline Initial Approval Rate & & & $.158^{\star * *}$ & $(4.29)$ & 1.17 \\
\hline Party Change & & & $1.19^{\star}$ & $(1.89)$ & 3.28 \\
\hline Months to Election & & & $-.027^{\star}$ & $(2.06)$ & .973 \\
\hline MP Hostility Level & & & $.073^{\star * *}$ & $(4.70)$ & 1.08 \\
\hline Target Hostility Level & & & $-.071^{\star * \star}$ & $(3.89)$ & .931 \\
\hline Initial Forces & & & $-1.1 \mathrm{e}-04^{* * *}$ & $(5.80)$ & 999 \\
\hline Additional Forces & & & $-.556^{\star \star \star}$ & $(7.20)$ & .573 \\
\hline Coalition & & & $1.61^{* * *}$ & $(3.61)$ & 4.99 \\
\hline Non-state Target & & & $2.55^{\star * *}$ & (3.44) & 12.82 \\
\hline Initial Support & & & .152 & $(.20)$ & 1.16 \\
\hline Humanitarian & & & $-2.04^{*}$ & $(1.79)$ & .129 \\
\hline Internal Political Change & & & $-2.86^{\star}$ & $(1.79)$ & .057 \\
\hline Unemployment & & & .048 & $(.10)$ & 1.04 \\
\hline Inflation & & & .022 & $(.14)$ & 1.02 \\
\hline FRA & & & $-1.98^{\star *}$ & $(2.56)$ & .137 \\
\hline UK & & & -1.38 & $(.64)$ & .214 \\
\hline Failures & 15 & 15 & & & \\
\hline$N$ (Intervention-Months) & 793 & 793 & & & \\
\hline
\end{tabular}

Robust $\mathrm{z}$ statistics ${ }^{* *} \mathrm{p}<0.001,{ }^{* *} \mathrm{p}<0.01,{ }^{\star} \mathrm{p}<0.05$

in the previous month, the partisanship of the chief executive, and the interaction of approval and partisanship. The results from this simplified model provide strong evidence for our hypotheses. Right party chief executives are less likely than left party executives to terminate a foreign military intervention in a given intervention-month when faced with low domestic popularity. As public approval rates decline, governments of the right become more likely to continue fighting and less likely to bring the troops home. For executives from parties on the left of the political spectrum, the risk of withdrawal is high when public approval is low, but left party executives become more likely to sustain military operations as their job approval ratings increase. Figure 1 illustrates the change in the relative hazard of "quitting" for right and left party executives as public approval of the executive increases from $30 \%$ to $80 \%{ }^{7}$ The

\footnotetext{
${ }^{7}$ The relative hazard of quitting means that in the model the hazard rates for two observations are proportional to one another and that proportionality is maintained over time. Mathematically the relative hazard for two observations in the data $i$ and $j$ obey the following relationship:
}

$$
\frac{h_{0}(t) e^{X i \beta}}{h_{0}(t) e^{X j \beta}}=\frac{e^{X i \beta}}{e^{X j \beta}}
$$

relative hazard of withdrawal from a military intervention short of victory is approximately equal for right and left party executives when between 45 and $55 \%$ of the public expresses approval of the chief executive. When less than $45 \%$ of the public approves of the chief executive, left party leaders are significantly more likely than right party leaders quit in the following month. Conversely, leaders from the political right have a low risk of withdrawal from a military intervention when public approval is low, but they significantly become more likely than left party leaders to cut their losses and bring the troops home when their popularity exceeds 55\%.

In Model 1a, we include our control variables. We also present hazard ratios for all the coefficients in column 3 of Table 1 . The hazard ratio for dichotomous variables is the ratio between the predicted hazard for a member of one group and that for a member of the other group, holding everything else constant. For continuous variables, the same interpretation applies to a one unit difference. The hazard ratio is calculated by taking the antilog of the coefficient. The first thing to note is that the coefficients on our key independent variables retain their signs and remain significant at $\mathrm{p}<.001$. 


\section{FIGURE 1 Predicted Relative hazard of "Quitting” by Executive Orientation}

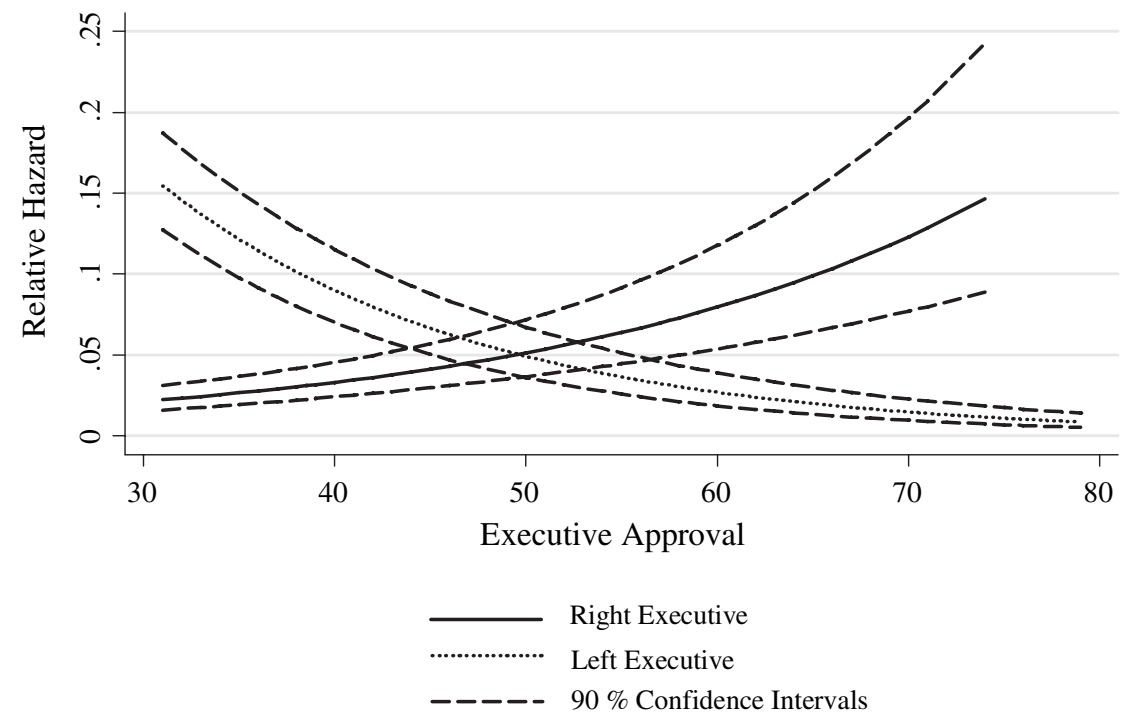

In addition, the magnitude of the effect of executive approval increases appreciably for both right and left party executives in the more specified model. We use the estimates from Model 1a to calculate changes in the risk of withdrawal as partisanship and approval change holding all other variables constant at their mean values. As public approval declines by one standard deviation (about 10 points, centered on the mean) the risk of withdrawal decreases by $52 \%$ for right party leaders. For left party leaders, the risk of quitting is thirteen times higher following a 10-point drop in public approval.

Although monthly unemployment levels and inflation rates do not appear to directly affect the timing of decisions to withdraw from a foreign military engagement, many of the control variables in Model 1a are significant. The higher an executive's public approval rates when the troops are deployed, the more likely the executive is to withdraw from the intervention short of victory. High public approval may make leaders more risk acceptant-increasing the likelihood they will select themselves into military engagements they cannot sustain to victory. At the same time, if the party holding the office of the executive changes during a military intervention, the risk of unilateral withdrawal more than doubles. National leaders may find it easier to disengage from failing foreign interventions if they are of a different party than the government that initiated the intervention. But it is also likely that public dissatisfaction with a failing war effort increases the probability that the party that initiated the war will be replaced. The negative coefficient on the election timing variable suggests that the further away the next election, the less likely the executive is to withdraw from an ongoing military commitment. Moving a month closer to the next mandated election increases the hazard of withdrawal by approximately $3 \%$. Although a number of unmeasured factors could account for divergence in the risk of withdrawal across countries, differences in the presidential term and executive constraints may partially account for why France appears to have a lower hazard of terminating a military intervention short of victory than the United States.

Turning next to the variables specific to the conflict, our measures of both major power and target hostility levels are significant. An increase in target hostility decreases the likelihood of withdrawal. However, holding all other variables constant, an increase in the level of hostility displayed by the intervening state leads to an increase in the hazard of the intervention ending in failure in the following month. These results provide some evidence for a "gambling for resurrection" phenomenon, although it is difficult to confirm this dynamic with data at this level of aggregation. When faced with losing an intervention, governments may escalate the conflict in a last-ditch effort to win-or at least not lose (Downs and Rocke 1994). Our measure of the cost of fighting in a particular engagement-the average number of battle deaths the intervening state suffered per month over the course of the intervention-was not significant either as an additional control variable 
or when included in the model instead of the hostility level variables. ${ }^{8}$

While the level of initial support for a military intervention does not change the expected duration of an intervention or the timing of withdrawal, both higher initial troop deployment levels and greater increases in troop numbers over the course of an intervention decrease the risk of quitting. For example, in a given intervention month, an intervening state is $21 \%$ less likely to withdraw from an intervention in which it initially deployed 3000 troops than from an intervention in which only 1,000 troops were initially committed. Not surprisingly, it seems that committing more troops to a foreign military intervention makes withdrawing more difficult. This result also suggests that troop commitment levels may be an indicator of the salience of the issues at stake for the intervening state. ${ }^{9}$ In contrast, the coefficient on the coalition variable is positive. It appears to be easier for a state to withdraw from an intervention when other major powers are engagedpossibly because quitting with allies is less damaging to a leader's domestic reputation or because states can withdraw their troops from a coalition effort without jeopardizing their security if their allies remain engaged.

We expected some types of military engagements to be more popular than others and for military intervention duration to vary with the nature of the major power's adversary and war aims. To measure war aims, we include the variables Internal Political Change and Humanitarian Intervention in the model, with Foreign Policy Restraint as the comparison category. Both are negative and significant suggesting that, all else equal, major power interventions to influence the composition of foreign regimes and peacekeeping operations tend to be longer than interventions to counter aggressive actions taken by foreign adversaries. Our results also suggest that the risk of withdrawal from a military intervention short of victory in any given month is significantly higher when the adversary is a nonstate actor as opposed to another state.

\footnotetext{
${ }^{8}$ Because this variable is relatively highly correlated with the intervening state's hostility level and including it does not change the substantive effects of our explanatory variables, we do not include it in the model presented in Table 1.

${ }^{9}$ An alternative measure of issue salience, which codes conflicts over territory or governance as more highly salient than conflicts over policy or humanitarian abuses, is not statistically significant as a control variable in Model 1a and including it does not significantly alter the coefficients on our key independent variables.
}

\section{Robustness Tests}

In order to test whether our results are unduly influenced by one or two unique or extreme cases, we estimated Model 114 separate times, excluding one of the failed interventions each time. The substantive effects and statistical significance of our explanatory variables did not change. We also estimated Model 1 for each country separately to see if the results varied significantly by country. While the coefficients were no longer significant due to the small number of cases, they remained signed in the same direction. The coefficients were also similar in magnitude for the U.S. and U.K. cases while the French coefficients were larger in magnitude.

As a final robustness check, we estimate a model using a measure of change in support for the executive among members of the executive's party for the U.S. and U.K. interventions. ${ }^{10}$ The new measure takes on a value of zero at the beginning of the intervention and when an executive of a different party takes office. The remaining values are the previous month's executive approval among partisans minus the initial level of support for the executive among party members. Our expectation is that declining partisan support for right executives will decrease the hazard of quitting while declining partisan support for left-leaning governments will increase the hazard of quitting.

We have fewer cases given the lack of French data, therefore we exclude those measures that were not significant in Model 1a in order to preserve as many degrees of freedom as possible. Table 2 presents these results. Both right executive and the interaction term are significant, while the change in approval measure for left party leaders is in the expected direction but insignificant. Figure 2 displays the marginal effect of executive partisanship on the hazard of quitting as support for the incumbent among his or her partisans changes.

Figure 2 shows there are significant differences in the hazard of quitting for governments of the left and right when partisan support declines. As approval of the executive decreases among his or her party members, right party governments become less likely to withdraw from a foreign military intervention without attaining the state's primary war aim, and

\footnotetext{
${ }^{10} \mathrm{We}$ are unable to obtain executive support by partisanship for the French cases. For U.S. executive support we use Gallup approval ratings broken down by partisanship. For the U.K. data we relied on National Opinion Polls from the U.K. data archive, Gallup polls, and MORI polls. Polls from the 1960s ask for a respondent's vote intentions rather than partisanship.
} 
TAble 2 Cox Proportional Hazard Models: Duration until Major Power withdraws from intervention, by change in incumbent party support.

\begin{tabular}{lr}
\hline & Model 2 \\
\hline Right Party Executive & $-.584^{\star *}(2.90)$ \\
Change in Support & $-.085(.59)$ \\
Right x Change in Support & $0.148^{\star *}(2.43)$ \\
Initial Approval Rate & $.040(1.60)$ \\
Party Change & $.112(.05)$ \\
Election Timing & $.002(.05)$ \\
MP Hostility Level & $.052(1.35)$ \\
Target Hostility Level & $-.080^{* *}(8.61)$ \\
Initial Forces & $-4.3 \mathrm{e}-05^{\star}(.97)$ \\
Total Forces & $-.413^{\star}(1.98)$ \\
Non-state Target & $.961^{\star}(1.71)$ \\
Failures & 10 \\
$N$ (Intervention-Months) & 643 \\
\hline
\end{tabular}

Robust $\mathrm{z}$ statistics ${ }^{\star * *} \mathrm{p}<0.001,{ }^{\star *} \mathrm{p}<0.01,{ }^{\star} \mathrm{p}<0.05$

the difference in the risk of withdrawal for right and left increases. When support for a government among its own partisan constituents has fallen 10 points below its level at the beginning of a military intervention, left-leaning executives are about 2.6 times more likely than right party executives to bring the troops home.

Model 2 provides additional evidence that left and right party executives respond to public approval ratings differently. But this model also highlights the importance of declining, rather than simply low executive approval levels. Two recent examples of executives involved in military interventions that do not appear in our dataset illustrate the distinction. Prior to the U.S. invasion of Iraq in March 2003, President Bush's approval ratings hovered around $58 \%$. By the end of April, they had climbed to approximately $70 \%$ as the United States made quick work of the Iraqi army. However, as the intervention continued, Bush's ratings declined, dropping to below $40 \%$ by December 2005. The President's approval ratings remained low, sometimes dipping into the 20s, for the rest of his term. As we would expect, the Republican president was steadfastly committed to sustaining the war effort for the remainder of his presidency.

In contrast, at first glance Prime Minister Blair's policy towards Iraq appears to be at odds with our predictions. Blair-a left party executive-chose not to withdraw British troops from Iraq despite approval ratings in the 30s. However, both Model 1 and Model 2 predict low relative hazard rates for Blair because support for the prime minister was already in the low 30s prior to the commitment of British troops to military operations in Iraq (Clarke et al. 2009). In fact, MORI polls suggest that Blair's approval stopped declining over the course of the intervention. If the prime minister's approval rates had been as high as President Bush's initially, a decline to approval in the

Figure 2 Marginal effect of Quitting: by Executive Orientation and Incumbent Partisan Support.

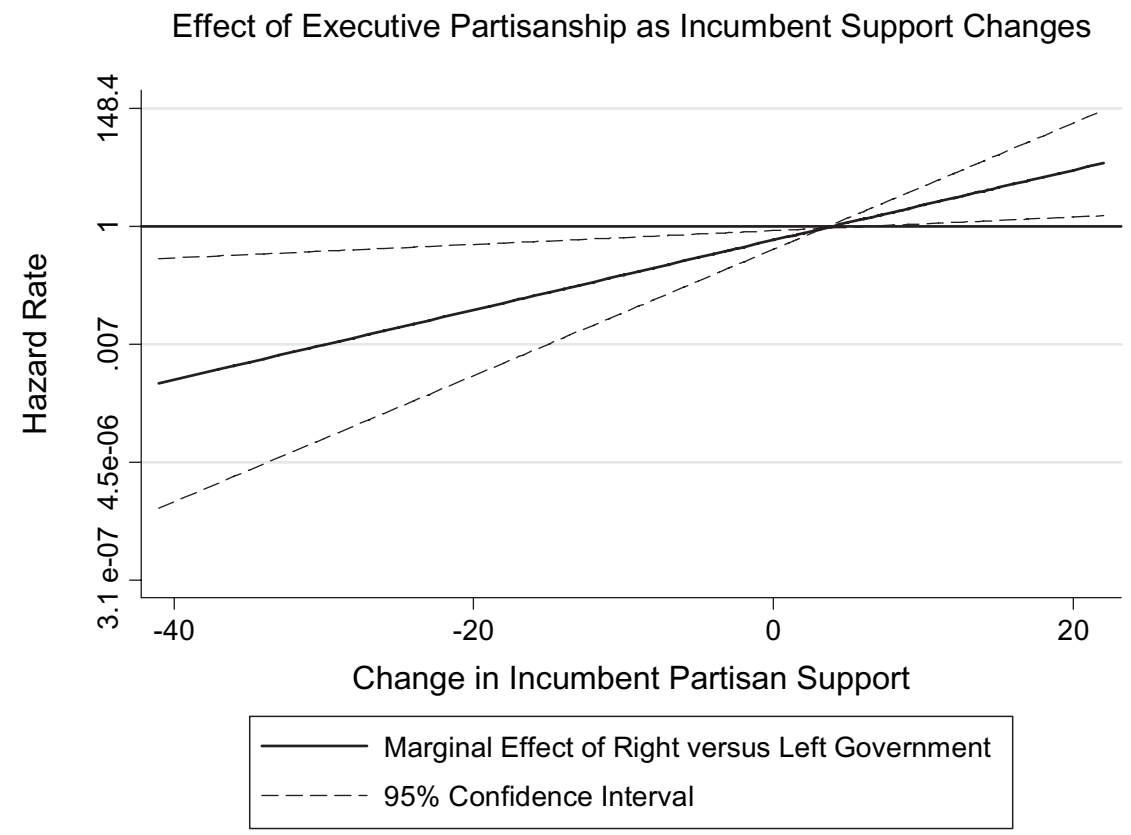


low 30s would have dramatically increased the risk that Blair would withdraw British troops from Iraq.

\section{Conclusion}

The analyses presented above provide evidence that partisan politics affects the policy preferences of national leaders and ultimately influences the duration of military interventions. We observe a strong relationship between domestic levels of approval for the chief executive and the timing of decisions to terminate foreign military interventions, but the direction of the effect varies with the partisanship of the chief executive. Overall, our results add to the mounting evidence that domestic politics extends well beyond the water's edge. Even after a country becomes involved in a war, political contests at home for control of the government have direct consequences for the foreign policies of democratic states, including the prosecution of conflicts already underway. As the United States' current wars in Iraq and Afghanistan demonstrate, both war fighting and war termination entail costs and risks for political leaders. The choice between sustaining a foreign military operation and bringing the troops home may depend largely on the anticipated consequences of each course of action for the security and prosperity of the state. However, domestic political concerns about sustaining public approval also appear to have a significant effect on the timing of military intervention termination. In their quest to retain power, governments of the left and right have different audiences to satisfy when they take office and their foreign policy choices reflect this. The electoral dilemmas that governments face when attempting to satisfy their constituents appear to bleed into the foreign policy realm.

This analysis builds on previous attempts to move beyond a democracy/nondemocracy dichotomy, adding depth to our understanding about how domestic politics affects conflict processes. Earlier research has suggested that democracies are more likely than nondemocracies to prevail in the wars they fight, but that their war-fighting advantages decline over time (Bennett and Stam 1998). Our results suggest that some democratic governments are more inclined than others to withdraw from foreign military engagements short of achieving their war aims. Moreover, deteriorating domestic political conditions can provide either incentives to sustain the fight or incentives to terminate a foreign military interven- tion depending on executive partisanship. We find executives from parties of the political right are less likely to terminate foreign military interventions when public approval of their job performance is low. But left party leaders become more likely to terminate foreign military interventions as their domestic popularity declines, even if they must withdraw short of victory.

A significant body of scholarship in international relations argues that democratic political institutions make leaders more sensitive to the human and material costs of using military force. Our results suggest that the extent to which democratic leaders are constrained by the costs of war varies widely. Leaders whose winning coalition is largely composed of constituents from parties on the right of the political spectrum appear to be less constrained by the costs of war fighting and more anxious to avoid termination of a war effort short of victory. The opposite is true for leaders whose base of support is on the left of the political spectrum.

These findings are consistent with conclusions drawn by other scholars: low levels of public approval appear to constrain the foreign policy options available to chief executives, while high levels of support give leaders the freedom to engage in more costly and risky policy pursuits (Foster and Palmer 2006; James and Oneal 1991; Ostrom and Job 1986). Robust job approval ratings allow left party executives to sustain foreign military interventions for longer durations, while high domestic approval ratings allow right party governments to terminate military engagements more quickly.

This analysis is one of only a handful of quantitative studies that tackle an enormously complex phenomenon-the timing of leaders' decisions to terminate their foreign military engagements. By combining a rationalist approach to war termination with a theory about how partisan politics affects the policy preferences of national leaders, we provide insight into why some military interventions by powerful democracies continue in the face of declining odds of victory while others are brought to a swift conclusion. However, because of the complex and reciprocal nature of the relationship between public opinion and foreign policy, there is still a great deal of work to be done.

\section{Acknowledgments}

We thank Ryan Bakker, Michael Colaresi, Brian Lai, Guy Whitten and the IR Group at Texas A\&M for 
their helpful comments and suggestions. We also thank Johannes Karreth, Doug Kuberski, Allison Shelton and Sam Snideman for their research assistance. The authors, however, are solely responsible for any errors or omissions. ${ }^{11}$

Manuscript submitted 24 April 2009

Manuscript accepted for publication 11 November 2009

\section{References}

Azar, Edward E. 1993. CONFLICT AND PEACE DATA BANK (COPDAB), 1948-1978 (Computer file). 3rd ICPSR release. College Park, MD: University of Maryland, Center for International Development and Conflict Management [producer], 1993. Ann Arbor, MI: Inter-university Consortium for Political and Social Research.

Baum, Matthew A. 2000. Tabloid Wars: The Mass Media, Public Opinion and the Decision to Use Force Abroad. Ph.d. diss. University of California, San Diego.

Bennett, D. Scott, and Allan C. Stam, III. 1996. "The Duration of Interstate Wars, 1816-1985." American Political Science Review 90 (2): 239-57.

Bennett, D. Scott, and Allan C. Stam, III. 1998. "The Declining Advantages of Democracy: A Combined Model of War Outcomes and Duration." Journal of Conflict Resolution 42 (3): 344-67.

Boix, Carles. 1998. Political Parties, Growth and Equality: Conservative and Social Democratic Economic Strategies in the World Economy. Cambridge, MA: Cambridge University Press.

Bond, Jon R., and Richard Fleisher. 1990. The President in the Legislative Arena. Chicago: University of Chicago Press.

Box-Steffensmeier, Janet M., and Bradford S Jones. 2004. Event History: Modeling: A Guide for Social Scientists. Cambridge and New York: Cambridge University Press.

Brace, Paul, and Barbara Hinkley. 1991. "The Structure of Presidential Approval: Constraints Within and Across Presidencies." Journal of Politics 53 (4): 993-1017.

Brody, Richard A. 1991 Assessing the President: The Media, Elite Opinion and Public Support. Stanford, CA: Stanford University Press.

Brody, Richard, and Lee Sigelman. 1983. "Presidential Popularity and Presidential Elections: An Update and Extension." Public Opinion Quarterly 47: 325-28.

Bueno de Mesquita, Bruce, and Randolph Siverson. 1995. "War and the Survival of Political Leaders: A Comparative Study of Regime Types and Political Accountability." American Political Science Review 89 (4): 841-55.

Bueno de Mesquita, Bruce, Alastair Smith, Randolph Siverson, and James Morrow. 2003. The Logic of Political Survival. Cambridge, MA: MIT Press.

Bueno de Mesquita, Bruce, Michael T. Koch, and Randolph M. Siverson. 2004. "Testing Competing Institutional Explana-

${ }^{11}$ An online appendix containing supplemental analyses for this article will be available at http://journals.cambridge.org/jop. Upon publication, data necessary to reproduce the numerical results in the paper will be made available at http://people. tamu.edu/ mtkoch/index 2 tions for the Democratic Peace" Conflict Management and Peace Science 21 (4): 1-13.

Butler, David, and Gareth Butler. 2000. Twentieth-century British Political Facts, 1900-2000. London: Palgrave Macmillan.

Chiozza, Giacomo, and H. E. Goemans. 2004. "International Conflict and the Tenure of Leaders: Is War Still Ex Post Inefficient?" American Journal of Political Science 48 (3): 60419.

Clarke, Harold D., David Sanders, Marianne C. Stewart, and Paul F. Whiteley. 2009. Performance Politics and the British Voter. Cambridge: Cambridge University Press.

DeRouen, Karl, Jr. 1995. "The Indirect Link: Economics, Politics, and Force.” The Journal of Conflict Resolution 39 (3): 671-96.

DeRouen, Karl, Jr. 2000. "Presidents and the Diversionary Use of Force." International Studies Quarterly 44: 317-28.

Downs, George W., and David M. Rocke. 1994. "Conflict, Agency, and Gambling for Resurrection: The Principal-Agent Problem Goes to War" American Journal of Political Science 38 (2): 362-80.

Eichenberg, Richard. 1989. Public Opinion and National Security in Western Europe. Ithaca, NY: Cornell University Press.

Erikson, Robert S. 1989. "Economic Conditions and the Presidential Vote.” American Political Science Review 83: 567-73.

Fearon, James D. 1994. "Domestic Political Audiences and the Escalation of International Disputes." American Political Science Review 88 (3): 577-92.

Feaver, Peter D., and Christopher Gelpi. 2004. Choosing Your Battles: American Civil-Military Relations and the Use of Force. Princeton, NJ: Princeton University Press.

Filson, Darren, and Suzanne Werner. 2007. "Sensitivity to Costs of Fighting Versus Sensitivity to Losing the Conflict: Implications for War Onset, Duration, and Outcomes." Journal of Conflict Resolution 51 (5): 691-714.

Fordham, Benjamin. 2002a. "Domestic Politics, International Pressure, and the Allocation of American Cold War Military Spending." Journal of Politics 64 (1): 63-88.

Fordham, Benjamin. 2002b. "Another Look at 'Parties, Voters, and the Use of Force Abroad." The Journal of Conflict Resolution 46 (4): 572-96.

Foster, Dennis M., and Glenn Palmer. 2006. "Presidents, Public Opinion, and Diversionary Behavior: The Role of Partisan Support Reconsidered." Foreign Policy Analysis 2 (3): 269-88.

Gartner, Scott, and Gary Segura. 1998. "War, Casualties and Public Opinion." The Journal of Conflict Resolution 42 (3): 278-300.

Gerner, D. J., P. A. Schrodt, R. A. Francisco, and J. L. Weddle. 1994. "The Machine Coding of Events from Regional and International Sources." International Studies Quarterly 38 (1): 91-119.

Goemans, Hein. 2000. War and Punishment: The Causes of War Termination in the First World War. Princeton, NJ: Princeton University Press.

Goldstein, Joshua S. 1992. "A Conflict-Cooperation Scale for WEIS Events Data." The Journal of Conflict Resolution 36 (3): 369-85.

Holsti, Ole R. 2004. Public Opinion and American Foreign Policy. Ann Arbor: University of Michigan Press.

Jacobson, Gary C. 1992. The Politics of Congressional Elections. $3^{\text {rd }}$ ed. New York: Harper Collins Publishers.

James, Patrick, and John Oneal. 1991. "The Influence of Domestic and International Politics on the President's Use of Force." The Journal of Conflict Resolution 35 (2): 307-32. 
James, Patrick, and Athanasios Hristoulas. 1994. "Domestic Politics and Foreign Policy: Evaluating a Model of Crisis Activity for the United States." The Journal of Politics 56: 327-48.

Jentleson, Bruce. 1992. "The Pretty Prudent Public: PostVietnam American Opinion on the Use of Military Force." International Studies Quarterly 36 (2): 49-74.

Jentleson, Bruce W., and Rebecca Britton 1998. "Still Pretty Prudent: Post-Cold War American Public Opinion on the use of Military Force." The Journal of Conflict Resolution 42 (4): 395-417.

Jordan, Donald L., and Benjamin I. Page. 1992. "Shaping Foreign Policy Opinions: The Role of TV News." The Journal of Conflict Resolution 36 (2): 227-41.

Kernell, Samuel. 1977. "Presidential Popularity and Negative Voting: An Alternative Explanation of the Midterm Congressional Decline of the President's Party." American Political Science Review 71 (1): 44-66.

Klingemann, Hans-Dieter, Richard I. Hofferbert, and Ian Budge (1994). "A Theory of Democratic Policymaking." In Klingemann, Hans-Dieter, Richard I. Hofferbert, and Ian Budge, Parties Policies, and Democracy. Boulder, CO: Westview, 1-19.

Koch, Michael T. 2009. "Governments, Partisanship and Foreign Policy: The Case of Dispute Duration" Journal of Peace Research 46 (6): 1-19.

Larson, Eric V. 1996. Casualties and Consensus: The Historical Role of Casualties in Domestic Support for U.S. Military Operations. Santa Monica, CA: RAND.

Lian, Bradley, and John Oneal. 1993. "Presidents, the Use of Military Force, and Public Opinion." Journal of Conflict Resolution. 37, 2: 277-300.

McCormick, James M., and Eugene R. Wittkopf. 1992. "At the Water's Edge: The Effects of Party, Ideology, and Issues on Congressional Foreign Policy Voting, 1947 to 1988." American Politics Research 20 (1): 26-53.

Meernik, James, and Peter Waterman. 1996. "The Myth of the Diversionary Use of Force by American Presidents." Political Research Quarterly 49 (3): 573-90.

Meernik, James. 2000. "Modeling International Crises and the Political Use of Military Force by the USA." Journal of Peace Research 37 (5): 547-62.

Meernik, James, and Chelsea Brown. 2007. "The Short Path and the Long Road: Explaining the Duration of US Military Operations" Journal of Peace Research 44 (1): 65-80.

Mitchell, Sara McLaughlin, and Will H. Moore. 2002. "Presidential Uses of Force during the Cold War: Aggregation, Truncation, and Temporal Dynamics." American Journal of Political Science 46 (2): 438-52.

Morgan, T. Clifton, and Kenneth N. Bickers. 1992. "Domestic Discontent and the External Use of Force." The Journal of Conflict Resolution 36 (1): 25-52.

Mueller, John E. 1973. War, Presidents and Public Opinion. New York: John Wiley and Sons.

Oneal, John R., Brad Lian, and James H. Joyner, Jr. 1996. “Are the American People Pretty Prudent?" Public Responses to U.S. Uses of Force, 1950-1988. International Studies Quarterly 40 (2): 261-79.

Oneal, John R., and Jaroslav Tir. 2006. "Does the Diversionary Use of Force Threaten the Democratic Peace? Assessing the Effect of Economic Growth on Interstate Conflict, 19212001.” International Studies Quarterly 50 (4): 755-79.

Ostrom, Charles, and Brian L. Job. 1986. "The President and the Political Use of Force" American Political Science Review 80 (2): 541-66.
Ostrom, Charles W., and Dennis Simon. 1985. "Promise and Performances: A Dynamic Model of Presidential Popularity." American Political Science Review 79 (3): 334-38.

Page, Benjamin I., and Richard A. Brody. 1972. "Policy Voting and the Electoral Process: The Vietnam War Issue." The American Political Science Review 66 (3): 979-95.

Palmer, Glenn, Tamar R London, and Patrick M. Regan. 2004 "What's Stopping You: The Sources of Political Constraints on International Conflict Behavior in Parliamentary Democracies." International Interactions 30 (1): 1-24.

Rivers, Douglas, and Nancy Rose. 1985. "Passing the President's Program: Public Opinion and Presidential Influence in Congress." American Journal of Political Science 29 (2): 18396.

Rohde, David W., and Dennis M. Simon. 1985. "Presidential Vetoes and Congressional Response: A Study of Institutional Conflict." American Journal of Political Science 29 (2): 397427.

Russett, Bruce. 1990. Controlling the Sword: The Democratic Governance of National Security. Cambridge, MA: Harvard University Press.

Schultz, Kenneth A. 2001. Democracy and Coercive Diplomacy. Cambridge, MA: Cambridge University Press.

Sigelman, Lee. 1979. A Reassessment of the Two Presidencies Thesis. The Journal of Politics 41 (4): 1195-1205.

Slantchev, Branislav. 2004. "How Initiators End Their Wars." American Journal of Political Science 48 (4): 813-29.

Sobel, Richard. 2001. The Impact of Public Opinion on US Foreign Policy since Vietnam. New York: Oxford University Press.

Stam, Allan C. 1996. Win Lose or Draw: Domestic Politics and the Crucible of War. Ann Arbor: Michigan University Press.

Sullivan, Patricia. 2007. "War Aims and War Outcomes: Why Powerful States Lose Limited Wars." Journal of Conflict Resolution 51 (3): 496-524.

Sullivan, Patricia, and Michael T. Koch. 2009. "Military Intervention by Powerful States, 1945-2003" Journal of Peace Research 46 (5): 707-18.

Tufte, Edward R., 1975. "Determinants of Outcomes of Midterm Congressional Elections.” American Political Science Review 69 (3): 812-26.

van der Brug, Wouter, 2001 "Analyzing Party Dynamics by Taking Partially Overlapping Snapshots." In Estimating the Policy Positions of Political Actors, ed. Michael Laver. London and New York: Routledge, 115-32.

Wagner, R. Harrison. 2000. "Bargaining and War." American Journal of Political Science 44 (3): 469-84.

Woldendorp, Jaap, Hans Keman, and Ian Budge. 2001. Party Government in 48 Democracies (1945-1998). CompositionDuration-Personnel. Dordrecht, Netherlands: Kluwer Academic Publishers.

Michael T. Koch is Assistant Professor of Political Science at Texas A\& M University, College Station, TX, 77845 .

Patricia Sullivan is Assistant Professor of Political Science in the Department of International Affairs at the University of Georgia. Athens, GA, 30602. 